\title{
The presentation of madness in the Victorian novel
}

\author{
Allan Beveridge, Consultant Psychiatrist, West Fife District General Hospital, \\ Dunfermline; and Edward Renvolze, Department of Community Medicine, Leeds \\ General Infirmary, Leeds
}

The major novelists of the Victorian era enjoyed a large readership amongst the general public. They dealt with the pressing social issues of the day and their work both reflected and shaped society's attitudes to contemporary problems. ${ }^{1}$ The 19 th century saw fundamental changes in society's response to the mentally ill with the creation of purpose-built asylums throughout the country. The Victorians were ambivalent in their reaction to the mentally disturbed. Whilst they sought to segregate the insane from the rest of the population, they were also terrified by the prospect of the wrongful confinement of sane people. ${ }^{2}$ The trial of Daniel McNaughton in 1843 for the assassination of Sir Robert Peel's Private Secretary, and the subsequent legislation, provoked general public debate about the nature of madness.

Many Victorian writers had personal experience of the effects of mental illness. Thackeray's wife became insane after the birth of their third child. BulwerLytton had his wife committed to a private asylum, although she later refuted the charge of insanity in her memoirs. Dickens visited asylums in England and America, and was also friendly with Dr John Conolly. Charlotte Brontë studied phrenology and, like her sisters, witnessed the psychological deterioration of her brother, Branwell. Charles Reade successfully campaigned for the release of a wealthy man he believed wrongfully confined in an asylum.

\section{Charlotte Brontë (1816-1855)}

In Charlotte Brontë's novel Jane Eyre (1847) we meet one of the most famous mad characters in 19th century fiction: Mrs Rochester. Her introduction is not encouraging:

\footnotetext{
"In the deep shade, at the further end of the room, a figure ran backwards and forwards. What it was, whether beast or human being, one could not, at first sight, tell: it grovelled, seemingly on all fours; it snatched and growled like some strange, wild animal: but it was covered with clothing: and a quantity of dark, grizzled hair, wild as a mane, hid its head and face."
}

There is no sympathy in this account, only fear and revulsion. Clearly, madness is seen as a state of degradation and bestiality. This is reinforced by referring to Mrs Rochester as "it" and later as a "clothed hyena" standing on "its hind feet". At one stage she is compared to a "Vampyre" and this occult allusion further emphasises the essential "otherness" of madness. In the novel we learn a little about her background but this only serves to increase her negative qualities. Thus she has a strong family history of insanity - "idiots and maniacs through three generations". Mrs Rochester spends her fictional existence hidden from view in the upper regions of Thornfield Hall and makes only occasional but gruesome appearances in the story. As Showalter ${ }^{3}$ has observed, madness had been banished from the drawing room.

A more sympathetic account of mental disturbance is to be found in Brontë's later semi-autobiographical novel Villette, published in 1853. The novel describes the mental turmoil of a young English teacher who goes to work abroad. The heroine, Lucy Snowe, has a "soon-depressed and easily deranged temperament". Her difficulties in adapting to her new environment and her unrequited romantic longings are shown as contributing to her psychological unease or "nervous fever". The portrayal is much more sympathetically drawn than that of Mrs Rochester. In part this was because Brontë was drawing on her own experiences of emotional distress whereas in Jane Eyre she relied on the stock Gothic images of madness.

\section{Emily Brontë (1818-1848)}

Emily Brontë's strange and compelling novel Wuthering Heights (1847) occupies a unique place in English literature and, unlike the other novels considered here, it is less concerned with the affairs of contemporary society than with the emotional and psychological lives of its individual characters. It is a complex novel and the depiction of madness reflects the interweaving themes of the work. Thus madness is seen to partake of the supernatural; the diabolical; the mystic; the expression of passion; and, more prosaically, the physical symptoms of illness.

In the novel, Catherine has two episodes of mental instability which are described in some detail. Interestingly, Emily Brontë was one of the first writers in English literature to use the term "mental illness". 
Catherine's actual decline into madness is well summarised by the housekeeper, Nellie Dean:

\footnotetext{
"It commenced in a quarrel. She was struck during a tempest of passion with a kind of fit .... she refused to eat, and now she alternatively raves and remains in a half-dream, knowing those about her, but having her mind filled, with all sorts of strange ideas and illusions".
}

Nellie Dean's account emphasises one of the key elements in Catherine's madness - the expression of her passionate nature which is contrasted with her husband's "cold blood".

In a passage which evokes the mystical aspect of her condition, Catherine is described as "altered ... but when she was calm, there seemed unearthly beauty in the change ... (her eyes) appeared always to gaze beyond, and far beyond - you would have said out of this world".

The association between Catherine's madness and diabolism is made when Heathcliff asks her on her sick bed if she is possessed by the devil. The physical aspects of her breakdown are noted in her inability to eat or sleep. Thus many disparate elements unite in this intricate picture of a mind of turmoil.

\section{Charles Dickens (1812-1870)}

On Boxing Day, 1851, Dickens visited St Luke's Hospital and described his impressions in Household Words. His account reveals a mixture of benign condescension, concern for suffering and a vague uneasiness bordering on revulsion. For Dickens insanity is a "terrible calamity" and represents the loss of "the greatest of Divine gifts". Such unfortunates should be treated with humanity and kindness - a theme Dickens enlarged upon in his novels.

Given Dicken's interest in the mentally "afflicted" and his crowded gallery of intriguing characters and eccentrics, it is surprising how infrequently mad people appear in his novels. When they do appear they are usually minor characters (Mr Dorritt in Little Dorritt is an exception).

Dicken's first fictional attempt to portray madness appears in Pickwick Papers (1837), when $\mathrm{Mr}$ Pickwick discovers A Madman's Manuscript in which a "madman" recounts his autobiography. The account is unconvincing and owes more to the literary conventions of madness than to clinical reality. Thus the "madman" has the standard Gothic attributes of maniacal laugh, superhuman strength and ability to strike "terror" in the hearts of sane men. We learn that the cause of his madness was "thoughtless riot, dissipation and debauchery".

A more sympathetic portrayal of madness occurs in David Copperfield (1850) in the character of $\mathrm{Mr}$ Dick. The origins of his derangement lie in his previous ill-treatment by his brother and his concern over his sister's unhappy marriage. Mr Dick's madness manifests itself mainly in his preoccupation with King Charles I's head and his belief that "some of the trouble"'in the King's head has been put into his own. We also learn that Mr Dick is engaged in writing a Memorial to the Lord Chancellor but, despite ten years endeavour, he had made very little progress.

Mr Dick is throughout referred to as "mild", "pleasant" and prone to "bursts of laughter". He is shown as a benign, harmless creature of simple demeanour, who enjoys playing with children. And yet there is something of the "idiot savant" about him as we learn that he is capable of making wise decisions and that Aunt Betsy relies on his judgement.

The novel relates that Aunt Betsy rescued Mr Dick from a private asylum, where he was ill-treated. He is treated kindly by Aunt Betsy and as a result is "the most friendly and amiable creature in existence". Thus Aunt Betsy appears as an early advocate of community care.

Of one of his later novels, Little Dorrit (1857), Angus Wilson" has written: "Never did Dickens so powerfully and with so much sophistication present such a gallery of neurotics". There are certainly many characters of interest to the student of psychological abnormality - Mrs Clennam, confined to her chair as a result of hysterical paralysis and unwilling to venture out of her house; Mr F's aunt, unpredictably suspicious and given to inappropriate obscure pronouncement; Maggy, whose previous harsh treatment has left her a good-natured simpleton, and Mr Dorrit in whom Dickens described in some detail the mental deterioration of a central character.

At the beginning of the novel Mr Dorrit is established in the Marshalsea debtor's prison and is obviously deriving benefit from institutional life in his role of self-appointed patriarch. The novel charts his psychological distintegration following his release from prison. He becomes increasingly suspicious and sensitive to imagined slights, culminating in his final mental collapse in which he becomes frankly deluded and disorientated. In his deranged state he achieves an honesty about himself which he has hitherto been at pains to conceal. As is usual with Dickens, however, Mr Dorrit's mental breakdown serves more of a literary purpose than the description of medical condition.

\section{Charles Reade (1814-1884)}

Charles Reade was a popular novelist in the Victorian era. In 1863 he published Hard Cash in which he depicted how easily sane people could be committed to lunatic asylums. The threat of wrongful confinement was an abiding Victorian fear and his novel created much debate amongst the public when it appeared. 
In Hard Cash, Mr Hardy arranges with asylum doctors to have his son, Alfred, committed to an asylum although he is perfectly sane. The novel portrays the asylum as a place of excessive cruelty and ignorance and shows the difficulty Alfred has in obtaining his release. Eventually, he is set free and the asylum doctors are seen to be fools, motivated only by financial gain.

The leading asylum doctor in the novel is $\mathrm{Dr}$ Wycherley who represents a satiric portrait of $\mathrm{Dr}$ John Conolly:

"Dr Wycherley; bland and bald, with a fine head, and a face naturally intelligent, but crossed every now and then by gleams of vacancy; a man of large reading and tact to make it subserve his interests. A writer on certain medical subjects, he had so saturated himself with circumlocution, that it distilled from his very tongue".

Dr Wycherley uses medical terminology to mask his ignorance and to bamboozle his patients. He declares Alfred Hardie to be suffering from "Incubation of Insanity" without even examining him.

Interestingly, despite the novel's avowed social concerns, it portrays mad people in a very unsympathetic light. The mad are seen as animalistic, cowardly, morally suspect and ultimately irredeemable. A major thrust of the book is the sense of disgust and horror that the reader is expected to feel at the prospect of being in the company of mad people - "the terror of a madhouse, which is natural to a sane man". Alfred's fellow inmates are described as follows:

\footnotetext{
"Here he was surrounded by the desperate order of maniacs he at present scarcely knew but by report. Throughout that awful night he could never close his eyes for the horrible unearthly sounds that assailed him. Singing, swearing, howling like wild beasts! . . his nose poisoned with ammoniacal vapours, and the peculiar wild beast smell that marks the true maniac."
}

In these images, we see that mad people are considered to have severed their connections with the rest of humanity. Reade repeatedly stresses the difference between the anonymous mass of almost subhuman asylum inmates and the novel's hero, Alfred Hardie, the representative of sanity. For all his moral indignation against wrongful confinement, Reade presents a deeply conservative picture of madness and his images of bestiality look back to 18 th century descriptions.

\section{Anthony Trollope (1815-1882)}

With Trollope's 1869 novel He Knew He Was Right a mad character is for once centre stage and the description of insanity comes closest to the clinical reality of mental illness. Trollope was clearly fascinated by the subject of madness. In 1869 he declared: "There is perhaps no great social question so imperfectly understood among us at the present day as that which refers to the line which divides sanity from insanity". He dealt with the topic of insanity in several of his novels e.g. Phineas Finn (1869), Lady Anna (1874), Phineas Redux (1876), Cousin Henry (1879) and Mrs Scarborough's Family (1883). His most detailed treatment of the subject was He Knew He Was Right which runs to over 900 pages. The novel depicts how Louis Trevelyan, a rich, welleducated English gentleman, becomes increasingly suspicious of his wife's fidelity. Trevelyan becomes preoccupied with his wife's alleged unfaithfulness to the exclusion of all else and the novel demonstrates the deleterious effect that this wreaks on his family and himself. Trollope terms Trevelyan's condition "monomania" and charts his social and physical deterioration leading ultimately to death. Modern day psychiatrists would doubtless recognise elements of morbid jealousy in the account of Trevelyan's illness. Sutherland ${ }^{5}$ has argued convincingly that Trollope based his description of Trevelyan's insanity on the work of Esquirol, who originated the term "monomania".

In Trollope's work madness is seen to be an evolving state with manifold consequences for both sufferer and family. Madness is seen to infiltrate to the very heart of society and it is no longer just an affliction of those on the periphery. Of all the Victorian novelists, Trollope presents the most sophisticated picture of madness.

\section{Other Victorian novels}

Madness makes sporadic appearances throughout other Victorian novels. In Wilkie Collins' The Woman in White (1860) wrongful confinement in an asylum forms a key element in the plot. The mentally afflicted Anne Catherick, the Woman in White, is sketchily drawn and madness is seen as a kind of childlike state. In Mrs Gaskell's Mary Barton (1848) mental illness makes a brief appearance at the end of the novel to explain the transformation of the heroine from fighter to demure wife. Mad characters play minor roles in George Gissing's The Nether World (1889) and in Ainsworth's Old St Paul's (1841).

\section{Conclusion}

A study of 19th century literature reveals the shifting Victorian attitudes to mental illness as fear and revulsion mix with humane concern. It is possible to detect a gradually more enlightened approach to madness evolving in the later works of Brontë, Dickens and Trollope. 


\section{References}

${ }^{1}$ ReED, J. (1975) Victorian Conventions. Athens, Ohio: Ohio University Press.

${ }^{2}$ McCandless, P. (1981) Liberty and lunacy: The Victorians and wrongful confinement. In Madhouses, Maddoctors, and Madmen: The Social History of Psychiatry in the Victorian Era. (ed. A. Scull). Philadelphia: University of Pennsylvania Press.

${ }^{3}$ SHOWALTER, E. (1981) Victorian woman and insanity. In
Madhouses, Mad-doctors and Madmen: The Social History of Psychiatry in the Victorian Era. (ed. A. Scull). Philadelphia: University of Pennsylvania Press. ${ }^{4}$ Wilson, A. (1972) The World of Charles Dickens. Harmondsworth: Penguin.

${ }^{5}$ Sutherland, J. (1985) Introduction to He Knew He Was Right by Anthony Trollope. (1869). Oxford: Oxford University Press.

\section{The Freud Museum}

\section{ThOMAS FaHY, Registrar, The Maudsley Hospital, London SE5}

Sigmund Freud spent the last year of his life at 20 Maresfield Gardens, an impressive redbrick Hampstead residence. The house was bought by his friends after the penniless psychoanalyst and his family fled from Vienna in 1938. His personal assets had been extorted from him by the authorities following the Anschluss of Austria to the Third Reich. When the family took up residence, Freud's daughter, Anna, organised his new study to resemble his Viennese consulting rooms. Before her own death in 1982 , Anna arranged for the house to become a museum in honour of her father. Once again the study was refashioned to Freud's original specifications. This time capsule was opened to the public in July 1986.

During his year in the house Freud, then aged 82, finished his last book Moses and Monotheism. This, he proclaimed, was an attempt to "reduce religion to a neurosis of humanity". Its publication in March 1939 coincided with Jewry's worst hour and many Jewish scholars visited Freud at his new home asking him to reconsider his decision to proceed with publication. He entertained several other distinguished guests during this period, including Dali and H.G. Wells. He also saw an average of four patients daily, mostly Jewish refugees like himself. In September 1939, the month the first German bombs were dropped on London, Freud finally succumbed to the "dear old cancer" which had plagued him for more than 16 years.
The museum is an elegant memorial to Freud. The souvenir car stickers and badges cannot detract from the skill and restrained good taste which have evidently been lavished on the restoration. Most work has been done on the preservation of Freud's study. The spectacles and open books on the desk are an effective theatrical ploy in such an evocative setting. The highlight of the room is the couch. with its colourful monogrammed blankets. It was a present from a patient and Freud brought it with him from Vienna in what must have been a superstitious reluctance to break up a successful partnership. Hanging incongruously above it, in full view of the reclining patient, is a lithograph depicting Charcot with a swooning hysteric performing in front of a distinguished audience at the Salpêtrière.

The study is lined with books, mainly on psychoanalysis, archaeology and literature. Freud maintained that he read more archaeology than psychology. However, the psychoanalytic collection is extensive and all the more impressive for the fact that Freud, directly or indirectly, had generated most of this material during his lifetime. But this was only a part of his original collection of books. Freud had to discard more than 800 volumes before coming to London. Freudian scholars suggest that he brought with him those books which had been an important influence on his work. The books he left behind were delivered to a Vienese bookseller who advertised 